\title{
WATER MANAGEMENT IMPACTS RICE METHYLMERCURY AND THE SOIL MICROBIOME
}

Sarah E. Rothenberg ${ }^{\mathrm{a}, *}$, Merle Anders ${ }^{\mathrm{b}}, \operatorname{Nadim~J.~Ajami~}^{\mathrm{c}}$, Joseph F. Petrosino ${ }^{\mathrm{c}}$, Erika Balogh ${ }^{\mathrm{d}}$ 


\section{ABSTRACT}

Rice farmers are pressured to grow rice using less water. The impacts of water-saving rice cultivation methods on rice methylmercury concentrations are uncertain. Rice (Oryza sativa L. cv. Nipponbare) was cultivated in fields using four water management treatments, including flooded (no dry-downs), alternating wetting and drying (AWD) (with one or three dry-downs), and furrowirrigated fields (nine dry-downs) ( $\mathrm{n}=16$ fields). Anoxic bulk soil was collected from rice roots during the rice maturation phase, and rice grain was harvested after fields were dried. Total mercury and methylmercury concentrations were determined in soil and polished rice samples, and the soil microbiome was analyzed using $16 \mathrm{~S}$ (v4) rRNA gene profiling. Soil total mercury did not differ between fields. However, compared to continuously flooded fields, soil and rice methylmercury concentrations averaged 51\% and 38\% lower in the AWD fields, respectively, and 95\% and $96 \%$ lower in the furrow-irrigated fields, respectively. Compared to flooded fields, grain yield was reduced on average by $<1 \%$ in the AWD fields and $34 \%$ in the furrow-irrigated fields. Additionally, using 16S (v4) rRNA gene profiling, the relative abundance of genera (i.e., highest resolution via this method) known to contain mercury methylators averaged 2.9-fold higher in flooded and AWD fields compared to furrow-irrigated fields. These results reinforce the benefits of AWD in reducing rice methylmercury concentrations with minimal changes in rice production yields. In the furrow-irrigated fields, a lower relative abundance of genera known to contain mercury methylators suggests an association between reduced soil and rice methylmercury and specific soil microbiomes.

Keywords: soil microbiota, aerobic, alternating wetting and drying, furrow-irrigation, Arkansas 


\section{INTRODUCTION}

Rice ingestion is an important dietary source for methylmercury $(\mathrm{MeHg})$, a potent neurotoxin (Hong et al., in press; Rothenberg et al., 2014). This is mainly attributed to cultivation of rice under standing water, which turns rice paddies into productive zones for mercury $(\mathrm{Hg})$ methylation (Rothenberg et al., 2014; Wyndham-Myers et al., 2014a). In submerged rice fields, anaerobic microorganisms convert less toxic inorganic $\mathrm{Hg}$ to $\mathrm{MeHg}$ (Alpers et al., 2014; MarvinDiPasquale et al., 2014; Rothenberg and Feng, 2012; Wyndham-Myers et al., 2014b), which is efficiently accumulated in rice grain (Rothenberg et al., 2011, 2012, 2015; Windham-Myers et al., 2014c; Yin et al., 2013). Microbial Hg methylation is typically concentrated in the oxic/anoxic interface (0-4 cm depth) (Marvin-DiPasquale et al., 2003); however, in rice paddies, pore water MeHg concentrations were highest up to $20 \mathrm{~cm}$ depth (Rothenberg and Feng, 2012). This is due in part to rice root exudates, including oxygen (Colmer, 2003) and labile carbon (Marvin-DiPasquale et al., 2014; Windham-Myers et al., 2014b). Root exudates increase the abundance and activity of anaerobic microbes at depth (Kim and Liesack, 2014), and promote dissolution of inorganic $\mathrm{Hg}(\mathrm{II})$, i.e. substrate for $\mathrm{Hg}$ methylating microorganisms (Rothenberg and Feng, 2012).

In Asia and the U.S., rice farmers are pressured to reduce freshwater use for rice cultivation (Bouman et al., 2007; California Air Resources Board, 2005; Farooq et al., 2009). Water reductions are needed 1) to help resolve water scarcity and increase water availability to other sectors (Bouman and Tuong, 2001; Bouman et al., 2007; Farooq et al., 2009), 2) to meet nutritional demands that accompany global population growth (Morison et al., 2008), 3) to mitigate methane emissions (i.e., greenhouse gases) from flooded paddies (California Air Resources Board, 2015; Linquist et al., 2015), and 4) to reduce groundwater depletion (Massey et al., 2014). Water-saving rice cultivation also reduces rice arsenic concentrations, an added benefit 
(Linquist et al., 2015). One of the most widely implemented methods is alternating wetting and drying (AWD), which involves multiple, carefully timed periods of nonsubmergence (Bouman et al., 2007). AWD is recommended over more aerobic rice cultivation methods (e.g., furrowirrigation) because rice yields are not compromised, while rice yields are reduced on average 16$34 \%$ using furrow-irrigation (Bouman et al., 2007).

More aerobic rice cultivation alters the activity and community structure of microorganisms in paddy soil (Kim and Liesack, 2015; Xiang et al., 2008); however the impact on soil and rice $\mathrm{MeHg}$ (increasing or decreasing) is uncertain. In rice fields in California, USA and Guizhou province, China, a single flooding/drying/reflooding cycle was associated with a 3-fold and 4-fold spike in soil MeHg concentrations, respectively (USA: Marvin-DiPasquale et al., 2014; China: Rothenberg and Feng, 2012). In the latter study, pore water sulfate also increased 5.3-fold, suggesting soil MeHg spiked in flooded paddies due to the revival of sulfate-reducing bacteria (Rothenberg and Feng, 2012), one of the most abundant microbial Hg methylators (Gilmour et al., 2013). Based on these limited results, spikes in soil $\mathrm{MeHg}$ following reflooding were hypothesized to correlate with elevated rice $\mathrm{MeHg}$ concentrations (Rothenberg et al., 2014). However, growing rice aerobically (under both greenhouse and field conditions) was associated with lower rice $\mathrm{MeHg}$ and total $\mathrm{Hg}$ ( $\mathrm{THg}$ ) concentrations compared to rice cultivated under flooded conditions (Peng et al., 2012; Wang et al., 2014). Differences may reflect the length of time paddy soil is aerobic and the number of reflooding cycles.

The primary objective of this study was to determine the effects of water management on soil and rice $\mathrm{THg}$ and $\mathrm{MeHg}$ concentrations using a range of water-saving cultivation methods, including continuously flooded fields, AWD fields (with one or three dry-downs), and furrowirrigated fields. In addition, the impacts of differential water management on soil microbial 
community structure were examined using $16 \mathrm{~S}$ rRNA gene profiling, including the relative abundances of bacterial and archaeal genera known to include microorganisms that methylate $\mathrm{Hg}$. We hypothesize that water-saving rice cultivation methods will reduce rice $\mathrm{MeHg}$ concentrations, and reduce the abundance of microorganisms that methylate $\mathrm{Hg}$. Results from this study will help inform water managers and rice farmers about water-saving rice cultivation methods that mitigate rice $\mathrm{MeHg}$ concentrations.

\section{MATERIALS AND METHODS}

Treatments and experimental design. In 2013, rice germplasm (Oryza sativa L. cv. Nipponbare) was obtained from the United State Department of Agriculture Genetic Stocks Oryza Collection (accession \# GSOR 100), and grown at the University of Arkansas Rice Research and Extension Center (Stuttgart, Arkansas) using four water treatments $\times$ four replicates ( $n=16$ fields). Fields were cultivated using a rice-soybean rotation. Each field was $260 \mathrm{~m}^{2}$; Nipponbare was planted in $3.3 \mathrm{~m}^{2}$ blocks at the end of each field and other rice varieties were cultivated in the remaining area. Grain yield $\left(\mathrm{Mg} \mathrm{ha}^{-1}\right)$ was determined for other rice varieties. All 16 fields were laid out in a randomized complete block design, and separated by packed levees to prevent water movement between plots.

There were four water management treatments ranging from anaerobic to aerobic: 1)

Flood, 2) AWD40-Flood, 3) AWD60, and 4) Row40 (=Furrow-Irrigated) (Fig. 1). Methods \#1-3 were previously described by Linquist et al. (2015). In flooded fields, water was maintained at 10 $\mathrm{cm}$ throughout the rice cultivation season. AWD fields were flooded to $10 \mathrm{~cm}$ depth and water subsided via evapotranspiration and percolation until soil moisture reached $40 \%$ or $60 \%$ of saturated volumetric water (measured at $5 \mathrm{~cm}$ depth). AWD40-Flood included one dry-down 
before rice plants reached the reproductive growth stage (green ring stage); after which a $10 \mathrm{~cm}$ flood was maintained. AWD60 included three dry-downs throughout the cultivation season.

Furrow-irrigated fields were dried until the soil reached $40 \%$ of saturation and then re-irrigated by flowing water down the rows; i.e., no standing water. There were a total of nine dry-downs in the furrow-irrigated fields.
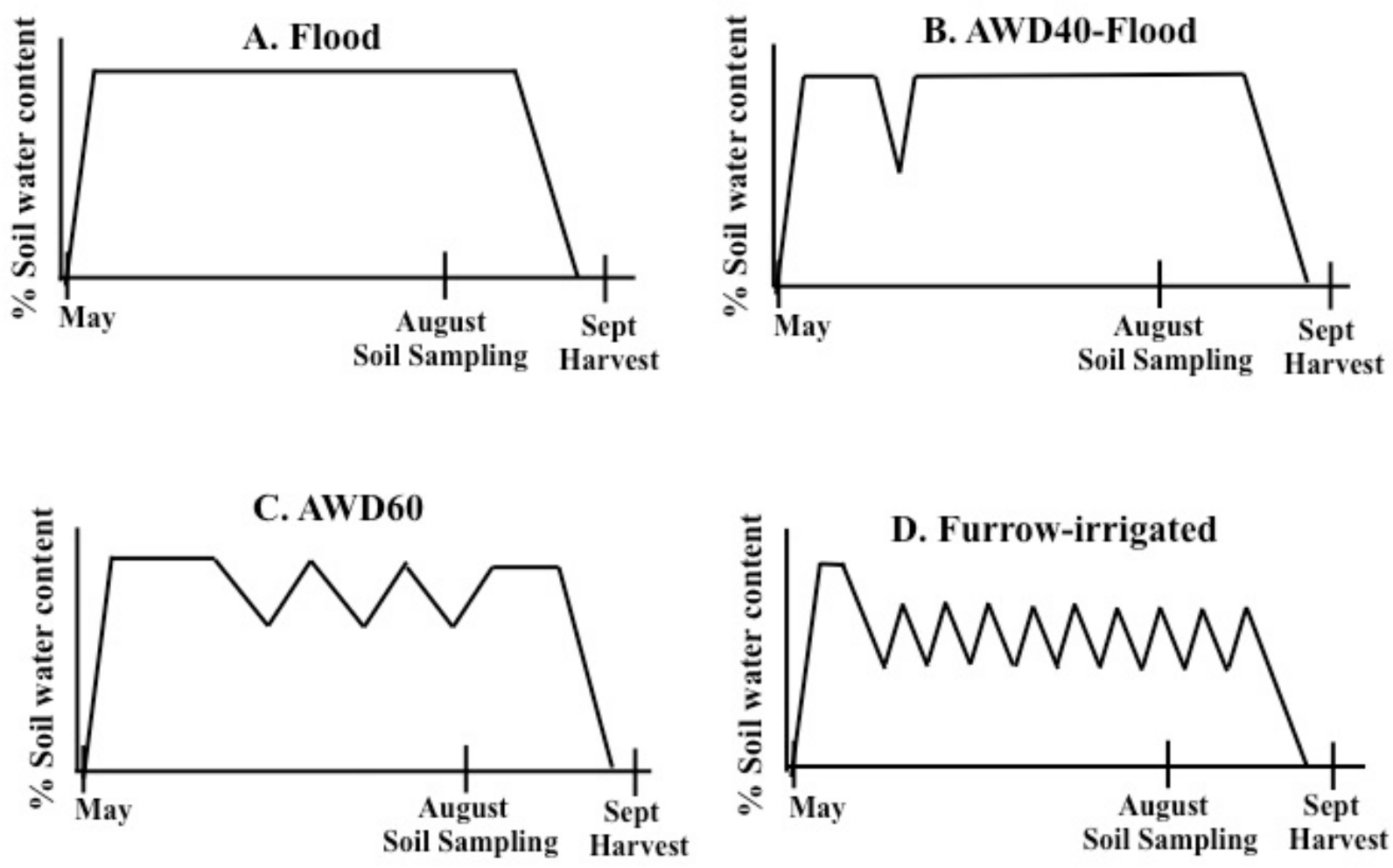

Figure 1. Water management treatments and timeline for a) continuously flooded fields, b) alternating wetting and drying (AWD) fields that were dried to $40 \%$ of saturation then re-flooded (1 dry-down), c) AWD60 fields dried to $60 \%$ of saturation then re-flooded ( 3 dry-downs), and d) furrow-irrigated fields, dried to $40 \%$ of saturation then row-irrigated ( 9 dry-downs).

Rice planting and sampling. The soil on all fields was a Dewitt silt loam (fine, smectitic, thermic, Typic Albaqualfs) with a total carbon content of $0.67 \%$, total nitrogen content of $0.075 \%$, and a pH of 5.6 (1:2 dry soil/water). Fertilizers (144, 29, $84 \mathrm{~kg}$ urea-nitrogen, phosphorous and potassium $\mathrm{ha}^{-1}$, respectively) were applied prior to the initial flood. 
On 23 April 2013, Nipponbare rice was planted in each plot by drill-seeding. On May 23 at the 4-5 leaf stage (i.e., tillering), all fields were flooded to $10 \mathrm{~cm}$ for $7-10$ days, then treatments were imposed as described above. In the AWD40-Flood fields, flooding resumed on July 5 (73 days after planting). On August 23 (122 days after planting), anoxic bulk soil was collected from rice roots into a plastic bag, and immediately frozen $\left(-20^{\circ} \mathrm{C}\right)$ in the field in a Credo ${ }^{\mathrm{TM}} \mathrm{Cube}$ (Pelican Biothermal, Plymouth, MN, USA). Frozen soil samples were transported to the University of South Carolina in a Credo ${ }^{\mathrm{TM}} \mathrm{Cube}$ then stored at $-80^{\circ} \mathrm{C}$ until analysis. All fields were dried down beginning August 25, and rice was harvested on September 26 (156 days after planting). Mature rice grain was composited from 10 randomly selected rice plants within each plot and stored in a paper bag, and dried at room temperature.

Frozen soil samples were collected for both $\mathrm{Hg}$ and microbiome analyses, and rice samples were collected for $\mathrm{Hg}$ analyses. $\mathrm{Hg}$ analyses were completed at the University of South Carolina, and the soil microbiome was analyzed using 16S rRNA gene profiling at Baylor College of Medicine, Alkek Center for Metagenomics and Microbiome Research.

Rice and soil Hg concentrations. Rice grain was dehulled (JLGJ4.5, China) and polished (Pearlest Grain Polisher, Kett Electric Lab, Tokyo, Japan), then ground to a powder (Capresso Grinder, USA). Instruments for polishing and grinding were cleaned with ethanol after each sample to prevent carry-over of $\mathrm{Hg}$.

Rice and soil $\mathrm{THg}$ concentrations were analyzed with a portable $\mathrm{Hg}$ vapor analyzer (Lumex, Model RA-915+/PYRO-915+, St. Petersburg, Russia) using thermal decomposition, amalgamation and atomic absorption spectrophotometry, and no pre-digestion steps were required [Environmental Protection Agency (EPA) 7473] (U.S. EPA, 2007). 
Rice MeHg concentrations were determined following solvent extraction and back extraction into water (Liang et al., 1996). Approximately $0.6 \mathrm{~g}$ of ground rice was weighed into 50 $\mathrm{mL}$ polypropylene tubes, and $2 \mathrm{~mL}$ of $25 \%(\mathrm{w} / \mathrm{v})$ potassium hydroxide-methanol were added and heated for $3 \mathrm{~h}\left(75^{\circ} \mathrm{C}\right)$. Then $6 \mathrm{~mL}$ of dichloromethane (DCM) were added, followed by addition of $1.5 \mathrm{~mL}$ of concentrated hydrochloric acid, then samples were shaken for $1 \mathrm{~h}$, centrifuged (4000 $\mathrm{RPM}=3220 \mathrm{~g}, 30 \mathrm{~min}$ ), and phases separated. Then $30-35 \mathrm{~mL}$ of double-distilled water were added, and samples were heated in a water bath $\left(65^{\circ} \mathrm{C}\right)$ for $1.5 \mathrm{~h}$ to volatilize DCM. Rice $\mathrm{MeHg}$ concentrations were quantified following EPA Method 1630 (U.S. EPA, 2001), including ethylation with sodium tetraethylborate, purge and trap onto Tenex traps (part \#06020, Brooks Rand), and separation of $\mathrm{Hg}$ species using gas chromatography and detection by cold vapor atomic fluorescence spectrometry (Brooks Rand, Model III, Seattle, WA, USA). Soil MeHg concentrations were determined after samples (approximately $2 \mathrm{~g}$ ) were leached in $1 \mathrm{~mL}$ of $1 \mathrm{M}$ copper sulfate, $4 \mathrm{~mL}$ of $25 \%$ nitric acid and $5 \mathrm{~mL}$ of DCM (Liang et al., 2004). Samples were shaken, centrifuged, phases separated, and DCM evaporated before MeHg extracts were quantified following EPA Method 1630, as described above (U.S. EPA, 2001). Soil aliquots were dried at $105^{\circ} \mathrm{C}$ overnight, and results reported in dry weight.

Quality assurance/quality control results are reported in Table 1. Average recovery for standard reference materials and/or matrix spikes ranged from $87 \%-102 \%$ for $\mathrm{THg}$ and $69-95 \%$ for $\mathrm{MeHg}$, and the relative percent difference between sample replicates averaged $9.3 \%$ for $\mathrm{THg}$ and $18 \%$ for MeHg. Detection levels were $1.2 \mathrm{ng} / \mathrm{g}$ for $\mathrm{THg}$ and $0.81 \mathrm{pg} / \mathrm{g}$ for MeHg. Half the detection level was imputed for one value for rice THg cultivated in furrow-irrigated fields. Soil microbiome and $16 \mathrm{~S}$ rRNA gene profiling. Frozen soil samples $\left(-80^{\circ} \mathrm{C}\right)$ were shipped overnight on dry ice to the Alkek Center for Metagenomics and Microbiome Research at Baylor 
College of Medicine in Houston, Texas. Microbial genomic DNA was extracted using the PowerSoil DNA Isolation Kit according to the manufacturer's instructions (MoBio Laboratories, CA, USA), and the concentration and purity of the extracted DNA were evaluated through gel electrophoresis and PicoGreen assays (Invitrogen, NY, USA).

The 16S rDNA V4 region was amplified by PCR using primers 515F and 806R (see Table A.1, and http://www.earthmicrobiome.org/emp-standard-protocols/16s/, last accessed 25 June 2016) (Caporaso et al., 2012). Sequencing was performed on the MiSeq platform (Illumina, CA, USA) using the $2 \times 250$ bp paired-end protocol, which yielded pair-end reads. The primers contained adapters for MiSeq sequencing and dual-index barcodes so that the PCR products were pooled and sequenced directly (Caporaso et al., 2012), targeting at least 15,000 reads per sample. The read pairs were demultiplexed based on the unique molecular barcodes, and reads were merged using USEARCH v7.0.1090 (Edgar, 2010), allowing zero mismatches and a minimum overlap of 50 bases. Merged reads were trimmed at first base with Q5. In addition, a quality filter was applied to the resulting merged reads and reads containing above 0.05 expected errors were discarded. 16S rRNA gene sequences were clustered into Operational Taxonomic Units (OTUs) at a similarity cutoff value of $97 \%$ using the UPARSE algorithm. OTUs were mapped to an optimized version of the SILVA Database (Quast et al., 2013), which contained only the 16S V4 region to determine taxonomies. Taxonomic abundances were recovered by mapping the demultiplexed reads to the UPARSE OTUs. Using a custom script, a rarefied OTU table was constructed for analyses of diversity (alpha- and beta-diversity) and phylogenetic trends.

Relative abundance of genera known to contain Hg methylators. Two proteins are essential for microbial $\mathrm{Hg}$ methylation, including a putative corrinoid protein that transfers a methyl group to $\mathrm{Hg}(\mathrm{HgcA})$ and a ferrodoxin protein that performs corrinoid reduction $(\mathrm{HgcB})$ (Parks et al., 
2013; Smith et al., 2015). There are 142 known species of bacteria and archaea (from 63 genera) that possess orthologs of the genes $h g c A B$ (http://www.esd.ornl.gov/programs/rsfa/data.shtml, last accessed 25 June 2016). When tested, all strains with $h g c A B$ homologs were proven $\mathrm{Hg}$ methylators (Gilmour et al., 2013). In addition, there are three genera containing verified $\mathrm{Hg}$ methylators for which the genome sequence is unavailable or incomplete (Gilmour et al., 2013), resulting in a total of 66 genera known to contain $\mathrm{Hg}$ methylators.

We searched the 16S (v4) rDNA genus-level abundances (i.e., highest resolution using this technology) for these 66 genera, and results were compared between four water management treatments. We combined genus-level relative abundances for Methanocella spp. and Rice-Cluster $1 \mathrm{spp}$. because Methanocello spp. includes some members belonging to the Rice-Cluster 1 lineage (Sakai et al., 2008).

Statistics. The effects of water management (Flood, AWD40-Flood, AWD60, and furrowirrigation) on paddy soil microbiota were examined using alpha- and beta-diversity. Alphadiversity (within sample diversity) was measured with the Chao1 index (richness) (Chao, 1984), the Shannon diversity index, and the observed number of sequences per sample. Beta-diversity analysis (between sample diversity) was calculated using the UniFrac distance metric (Lozupone and Knight, 2005). The unweighted UniFrac distance does not take taxa abundance into consideration and is thus more sensitive to rarer taxa, while the weighted UniFrac measure takes abundance into account. Differences between taxonomic groups (including alpha- and betadiversity patterns) were assessed using one-way analysis of variance (ANOVA) and TukeyKramer multiple-comparison test. Rice and soil $\mathrm{THg}$ and $\mathrm{MeHg}$ concentrations were compared between the four water management treatments using Kruskal-Wallis test. 
For all analyses, an alpha level of 0.05 was chosen as a guide for significance. Statistical analyses were completed using the R-platform or Stata (Version 9.2, College Station, TX, USA).

Nucleotide Sequence Accession numbers. Illumina data are found in the National Center for Biotechnology Information (NCBI) Sequence Read Archive under the study accession number SRP064901. Accession numbers of sequences are SAMN04169009 to SAMN04169024.

\section{RESULTS}

Rice yield. For other rice varieties cultivated in the same fields, the average grain yield was 11.22 $\mathrm{Mg} \mathrm{ha}^{-1}, 11.53 \mathrm{Mg} \mathrm{ha}^{-1}, 10.70 \mathrm{Mg} \mathrm{ha}^{-1}$ and $7.38 \mathrm{Mg} \mathrm{ha}^{-1}$ in the continuously flooded fields, AWD40-Flood fields, AWD60 fields, and furrow-irrigated fields, respectively (Table 2). Compared to flooded fields, rice yield averaged 34\% lower in furrow-irrigated fields, which was consistent with values reported by Bouman et al. (2007) for furrow-irrigated fields, i.e., 16-34\%.

Soil and rice Hg. Concentrations of soil THg did not differ between all fields (KruskalWallis, $\mathrm{p}=0.34$ ); however soil $\mathrm{MeHg}$ concentrations and soil \% MeHg (of THg) differed (KruskalWallis, $\mathrm{p}=0.03$ for both) (Fig. 2a-c, Table 2). Compared to continuously flooded fields, soil MeHg concentrations were reduced on average by 29\%, 73\% and 95\% in AWD40-Flood, AWD60, and furrow-irrigated fields, respectively. Likewise, compared to continuously flooded fields, average soil \% MeHg (of THg) was reduced by 27\%, 73\%, and 96\% in AWD40-Flood, AWD60, and furrow-irrigated fields.

Compared to continuously flooded fields, rice THg concentrations were 47\%, $28 \%$ and 99\% lower in AWD40-Flood, AWD60, and furrow-irrigated fields, respectively (Kruskal-Wallis, p=0.02) (Fig. 2d). Similarly, rice MeHg concentrations were 52\%, 31\% and 95\% lower in AWD40-Flood, AWD60, and furrow-irrigated fields, respectively, compared to flooded fields 
(Kruskal-Wallis, $\mathrm{p}=0.03$ ) (Fig. 2e). Rice \% MeHg (of THg) was also significantly different between fields, with lowest values in the furrow-irrigated fields compared to the other water management treatments (Kruskal-Wallis, $\mathrm{p}=0.02$ ) (Fig. 2f). Lower soil and rice MeHg concentrations suggested reduced soil $\mathrm{Hg}$ methylation, while lower rice $\mathrm{THg}$ suggested reduced bioavailability of inorganic $\mathrm{Hg}(\mathrm{II})$ from paddy soil. Thus water management potentially mitigated rice $\mathrm{Hg}$ concentrations through at least two mechanisms.
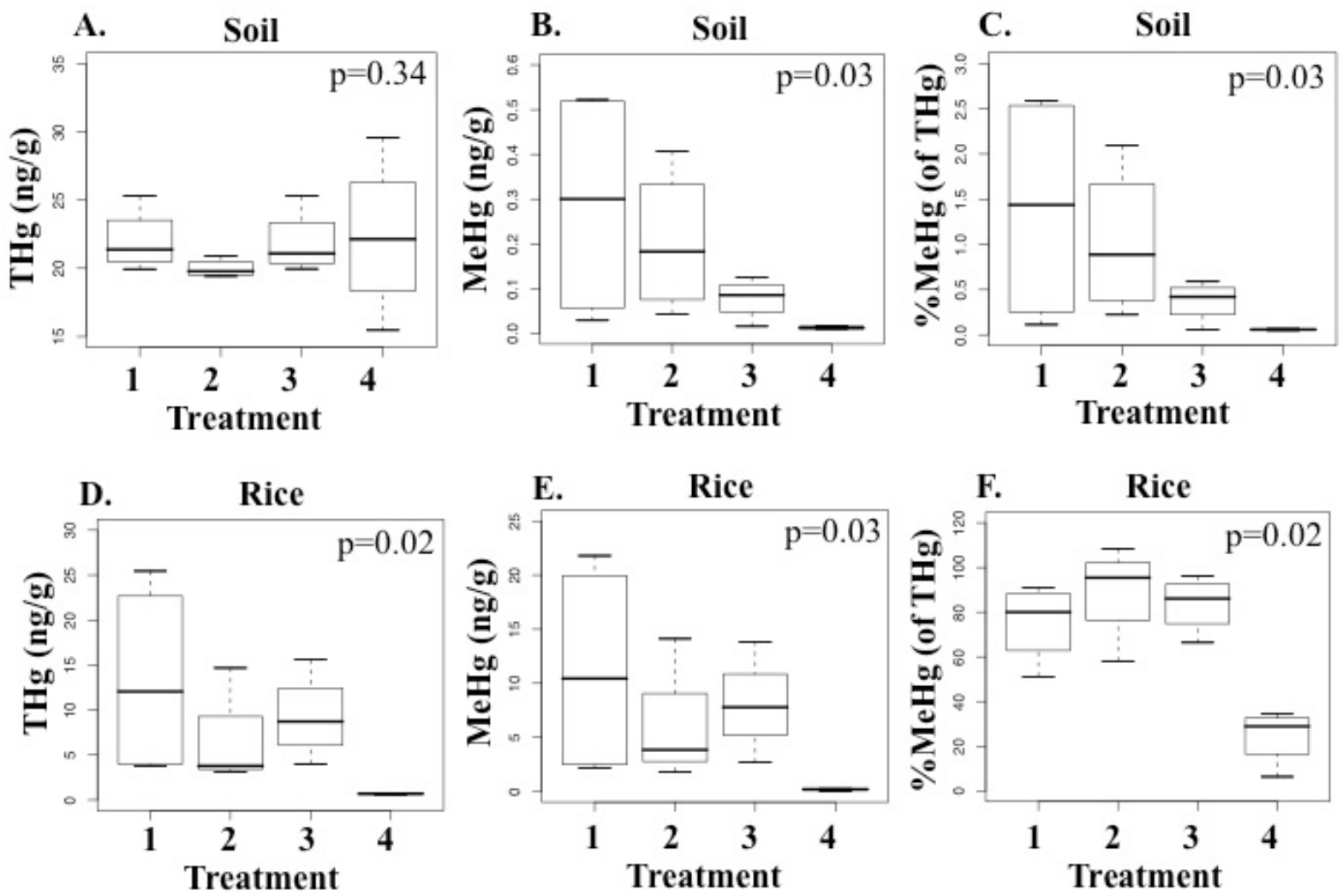

Figure 2. Box plots for soil (a-c) and polished rice (d-f) concentrations of total mercury (THg), methylmercury (MeHg), and \% MeHg (of THg), for rice cultivated in fields using four water management treatments: 1) Flood, 2) AWD40-Flood, 3) AWD60, and 4) Furrow-irrigated (n=16 fields). p-values are for Kruskal-Wallis tests.

The bioaccumulation factor (BAF) (unitless) is defined as the ratio between polished rice $\mathrm{Hg}$ and soil $\mathrm{Hg}$. BAF averaged 320 times higher for MeHg compared to THg [BAF MeHg/BAF THg, range $=20-1100$ (unitless), median $=190$ (unitless)], suggesting greater translocation of $\mathrm{MeHg}$ from soil to the rice endosperm (Table 2). Alternatively, BAF may be higher for $\mathrm{MeHg}$ 
compared to $\mathrm{THg}$ because inorganic $\mathrm{Hg}$ may be lost through rice foliage (Yin et al., 2013). Higher BAF for MeHg compared to THg was previously reported for other sites (mostly in Guizhou, China) [BAF MeHg/BAF THg, range = 18-6300 (unitless), median = 550 (unitless), n=6 studies ] (Rothenberg et al., 2014), although the median value for the present study was lower (190). Soil microbiome. The number of mapped $16 \mathrm{~S}(\mathrm{v} 4)$ rDNA reads for 16 soil samples averaged 27617; analyses were performed on an equal number of mapped reads per sample (15,060 reads) (Fig. A.1). 16S (v4) rDNA reads mapped to 2756 OTUs, which were assigned to 23 phyla, including 686 genera. Across all 16 fields, 13 phyla represented 95\% of OTUs.

Proteobacteria and Acidobacteria were the most abundant phyla (averaging $25 \%-40 \%$ relative abundance), followed by Verrucomicrobia, Bacteroides and Actinobacteria (averaging 5.2\%-5.9\% relative abundance), and eight additional phyla averaging $<1 \%-2.8 \%$ relative abundance (Fig. 3 ). The most abundant genera for all treatments (ranked from highest to lowest abundant) were: Anaeromyxobacter, Sphingomonas, Denitratisoma, Geobacter, Haliangium, and Bryobacter (averaging 1.7\%-2.9\% relative abundance), and eight additional unclassified genera (averaging 1.5\%-13\% relative abundance) (Fig. 4). Across flooded or AWD fields, 14 genera comprised 50\% of OTUs; however, the same genera comprised only $34 \%$ of OTUs in furrow-irrigated fields. 


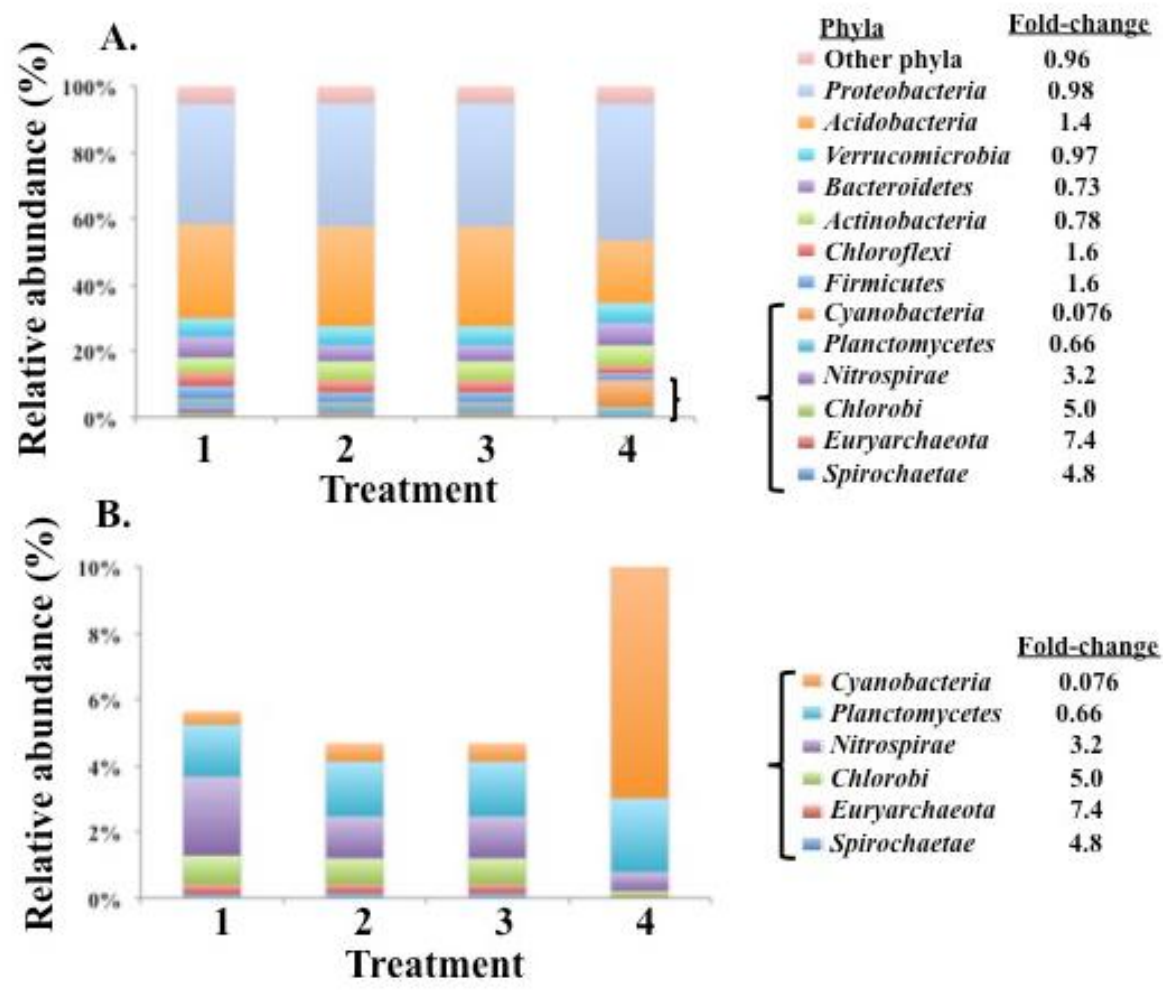

Figure 3. Percent relative abundance (phylum-level) for microorganisms in anoxic bulk soil from rice fields using four water management treatments: 1) Flood, 2) AWD40-Flood, 3) AWD60, and 4) Furrow-irrigated (n=16 fields), including (A) 13 phyla and "other phyla," while (B) represents six (of 13) phyla. The fold-change reflects the ratio between treatments 1-3 (flooded and AWD) and treatment 4 (furrow-irrigated).

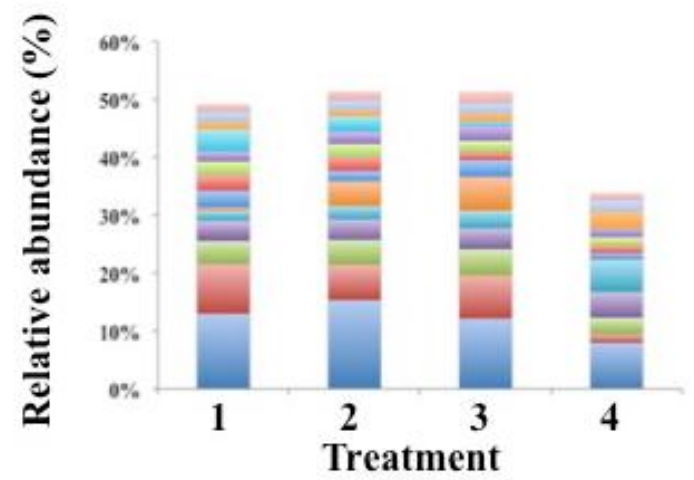

\begin{tabular}{|c|c|}
\hline Genera & Eold-change \\
\hline Uncl. Proteobacteria & 1.3 \\
\hline = Bryobacter & 0.84 \\
\hline$=$ Haliangium & 0.45 \\
\hline$=$ Uncl. Bacteroidetes & 1500 \\
\hline$=$ Uncl. Acidobacteria & 1.4 \\
\hline - Uncl. Acidobacteria & 1.4 \\
\hline$=$ Uncl. Acidobacteria & 1.8 \\
\hline = Geobacter & 2.2 \\
\hline Denitratisoma & 150 \\
\hline = Sphingomonas & 0.39 \\
\hline$=$ Uncl. Proteobacteria & 0.83 \\
\hline = Uncl. Verrucomicrobia & 1.5 \\
\hline = Anaeromyxobacter & 4.9 \\
\hline$=$ Uncl. Acidobacteria & 1.8 \\
\hline
\end{tabular}

Figure 4. Percent relative abundance (genus-level) for microorganisms in anoxic bulk soil from rice fields using four water management treatments: 1) Flood, 2) AWD40-Flood, 3) AWD60, and 4) Furrow-irrigated ( $n=16$ fields). The fold-change reflects the ratio between treatments 1-3 (flooded and AWD) and treatment 4 (furrow-irrigated). 
Indices for microbial richness (i.e., alpha-diversity) did not differ significantly between treatments ( $\mathrm{p}=0.71-0.96$, Fig. A.2). However, unweighted and weighted beta-diversity patterns differed between treatments; specifically, observations for furrow-irrigated fields were disconnected from other fields (i.e., Flood, AWD40-Flood, and AWD60 fields) (for both: $\mathrm{p}<0.05$ and r-squared=0.36) (Fig. 5). Differences between soil microbiotas were explained in part by the relative abundance of anaerobes and aerobes. For example, the phylum Euryarchaeota (including methanogens) averaged 7.4-fold higher in flooded and AWD fields compared to furrow-irrigated fields, while Cyanobacteria (found in oxic environments, from Kim and Liesack, 2015) averaged 13-fold higher in furrow-irrigated fields compared to other water management treatments (Fig. 3). At the genus-level, the relative abundance of the Geobacter spp., Anaeromyxobacter spp., and Denitratisoma spp. (all anaerobes) were 2.2-, 4.9-, and 150-fold higher, respectively, in flooded or AWD fields compared to furrow-irrigated fields, while Sphingomonas spp. and Haliangium spp. (all aerobes) were 2.2- and 2.6-fold higher, respectively, in furrow-irrigated fields compared to flooded or AWD fields (Fig. 4).
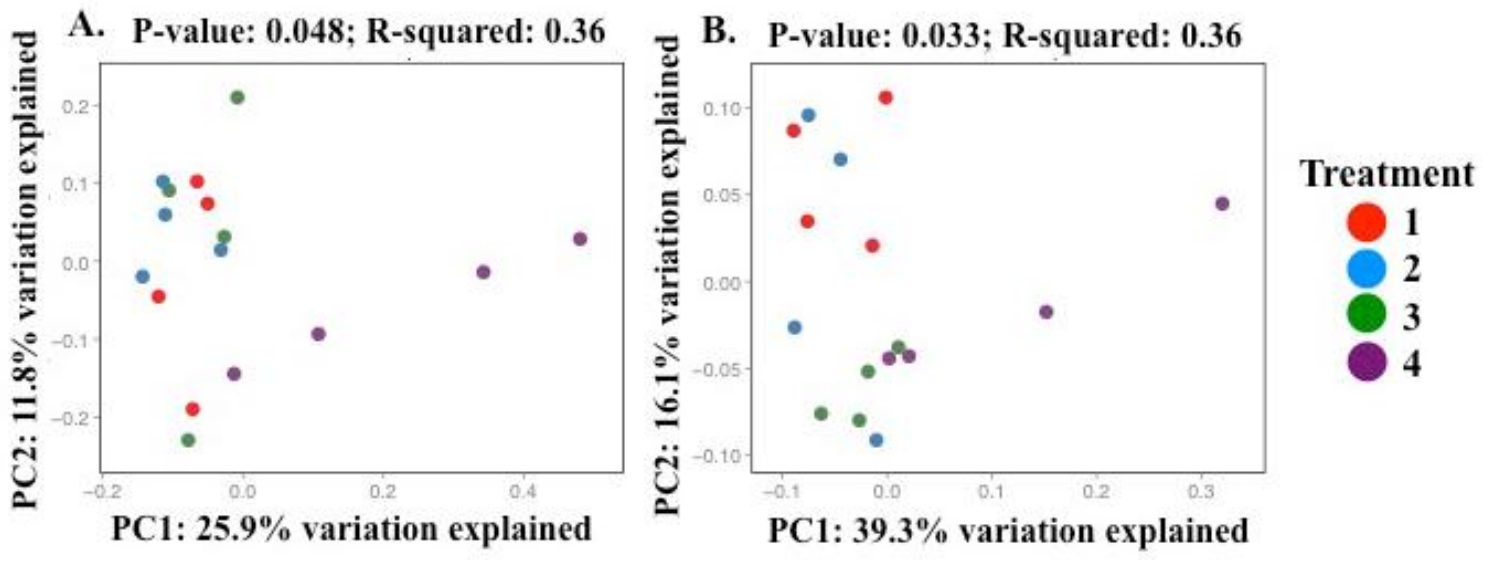

Figure 5. Unweighted (a) and weighted (b) UniFrac analysis of soil microbiota analyzed from rice fields using four water management treatments: 1) Flood, 2) AWD40-Flood, 3) AWD60, and 4) Furrow-Irrigated ( $n=16$ fields, 4 per treatment). 
Microbial Hg methylators in the soil microbiome. The list of genera identified using $16 \mathrm{~S}$ (v4) rDNA profiling was searched for 66 genera known to include microbes that methylate $\mathrm{Hg}$ (Fig. 6, Table 3). A total of six phyla were present, including 16 genera [Proteobacteria (eight genera), Euryarchaeota (three genera), Chlorflexi (two genera), Firmicutes (one genus), Spirochaetea (one genus), and Bacteroidetes (one genus)]. In other studies, PCR primers were developed for the Hg methylation gene, $h g c A$, and the diversity of $h g c A$ was investigated in wetland soil (Bae et al., 2014; Liu et al., 2014; Schaefer et al., 2014). Analysis of $h g c A$ gene sequences indicated four of the same phyla were also present in rice paddy soil from Wanshan, Guizhou province, China (Proteobacteria, Euryarchaeota, Chlorflexi, and Firmicutes) (Liu et al., 2014), and in wetland soil from the Florida Everglades (Bae et al., 2014), while three of the same phyla (Proteobacteria, Euryarchaeota, Chlorflexi) were present in wetland soil from the Florida Everglades and from Sweden (Schaefer et al., 2014).

In total, the 16 genera known to contain microbes that methylate $\mathrm{Hg}$ comprised on average $4.0 \%, 2.3 \%, 4.1 \%$, and $1.2 \%$ relative abundance in flooded, AWD40-F, AWD60 and furrowirrigated fields, respectively, and averaged 2.9-fold higher in flooded and AWD fields, compared to furrow-irrigated fields (Table 3). Geobacter spp. were the most abundant in all treatments (range: 1.1\%-2.9\% relative abundance), and averaged 2.2-fold higher in the flooded and AWD fields compared to furrow-irrigated fields. Not all genera were present in all fields; one-two genera were absent in the flooded and AWD fields, while 10 genera were absent in the furrow-irrigated fields. Among the remaining six genera, Methanocella spp., and Desulfovibrio spp. averaged 51fold and 17-fold higher, respectively, in the flooded and AWD fields compared to furrow-irrigated fields. This genus includes Methanocella paludicola SANAE (Sakai et al., 2008) and Methanocella arvoryzae MRE50 (RC-1) (Sakai et al., 2010), which are isolates from rice paddies, while 
Desulfovibrio spp. include sulfate-reducing bacteria, an important Hg methylator (Gilmour et al., 2013). Dehalobacter spp. FTH1 were also isolated from rice paddy soil (Yoshida et al., 2009) and contain $h g c A B$ orthologs (Gilmour et al., 2013), however, this genus was absent from all fields.

A. Flooded

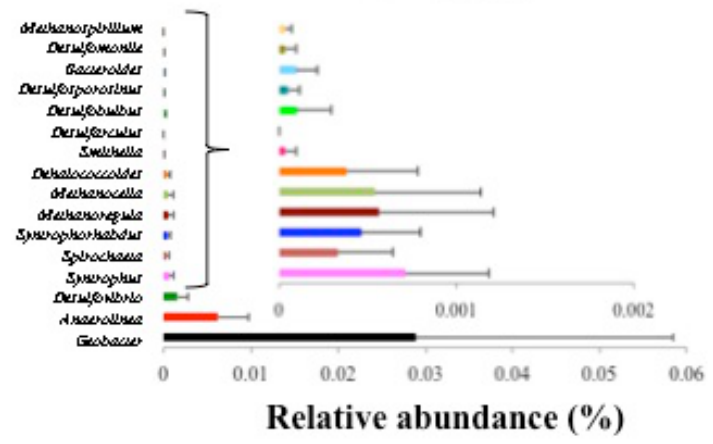

C. AWD60

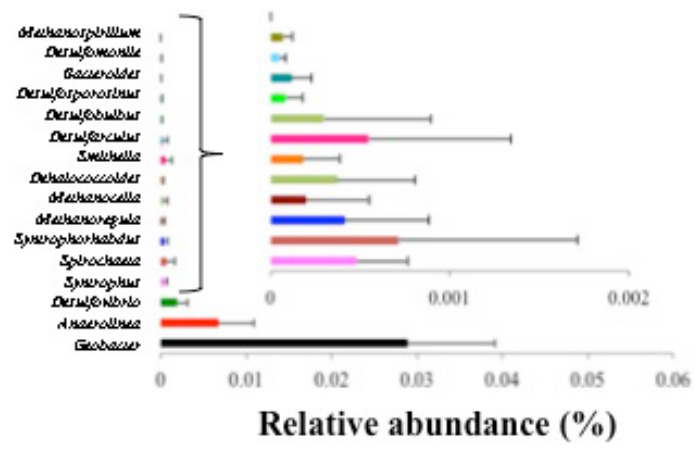

B. AWD40-Flood

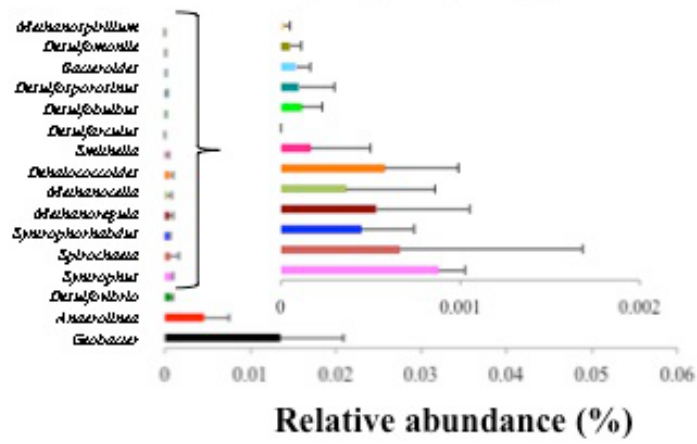

D. Furrow-irrigated

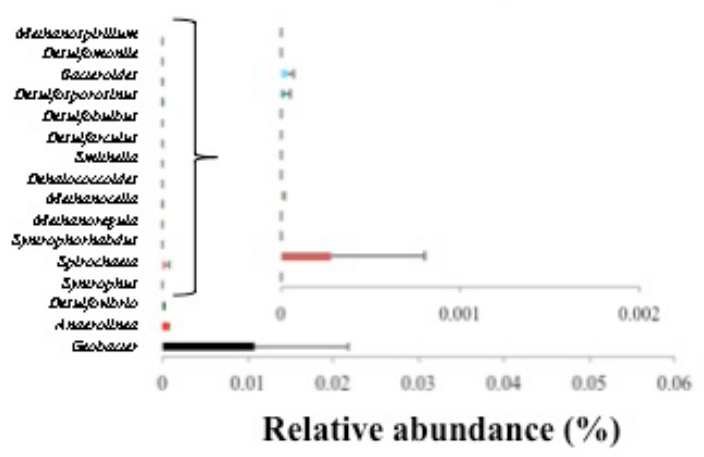

Figure 6. Average ( \pm SD) percent relative abundance of 16 genera known to include microorganisms that methylate mercury, analyzed in rice paddy soil: A) Flooded, B) AWD40-Flood, C) AWD60, and D) Furrow-irrigated ( $n=16$ fields). Each figure includes 16 genera ranging from $0 \%-0.06 \%$ relative abundance, and a smaller figure including 13 (of 16) genera ranging from $0 \%-0.002 \%$ relative abundance.

\section{DISCUSSION}

Impacts of water management on soil and rice $\mathrm{MeHg}$ concentrations were investigated in flooded fields, AWD fields (one or three dry-downs), and furrow-irrigated fields (nine dry-downs). Compared to continuously flooded fields, soil $\mathrm{MeHg}$, rice $\mathrm{THg}$, and rice $\mathrm{MeHg}$ concentrations averaged $27-73 \%$ lower in the AWD fields, and 95-96\% lower in furrow-irrigated plots.

Differences between furrow-irrigated and flooded fields in our study were consistent with previous 
studies reporting lower rice $\mathrm{MeHg}$ cultivated under more aerobic conditions (Peng et al., 2012; Wang et al., 2014).

The decrease in soil and rice $\mathrm{MeHg}$ concentrations between flooded, AWD, and furrowirrigated fields suggested the length of time fields were aerobic, and intensity of aerobic conditions (AWD versus furrow-irrigation) were important factors in understanding the impacts of water management on soil and rice $\mathrm{MeHg}$. These factors may also help explain differences between studies investigating AWD and more aerobic rice cultivation methods.

It is well known that microbial communities in paddy soil change over time after flooding (Kim and Liesack, 2015; Edwards et al., 2015). At circumneutral pH, after oxygen is depleted, denitrification commences, followed by manganese and iron reduction, sulfate reduction, methanogenesis, and fermentation. Microbes that contain the gene cluster required to methylate $\mathrm{Hg}$ $(h g c A B)$ are primarily anaerobic, including sulfate-reducers, iron-reducers and methanogens (Gilmour et al., 2013). As conditions become more anoxic, Hg methylation increases (Kelly et al., 1997).

For these 16 fields, beta-diversity patterns (weighted and unweighted UniFrac analysis) indicated furrow-irrigated fields differed from AWD and flooded fields (Fig. 5). Differences were mainly attributed to greater relative abundance of aerobes in the furrow-irrigated fields (e.g., Cyanobacteria phylum), while anaerobes were more depleted (e.g., Euryarchaeota phylum) (Fig. 4). As anaerobes decreased, the likelihood for $\mathrm{Hg}$ methylation was also reduced. For example, Methanocella spp. and Desulfovibrio spp. were 51-fold and 17-fold more abundant in flooded and AWD fields compared to furrow-irrigated fields, respectively (Table 3, Fig. 6). Wang et al. (2014) also reported depletion of sulfate-reducing bacteria in aerobic rice fields. Results from our analyses suggested longer oxidation periods in the furrow-irrigated fields were sufficient to reduce 
anaerobic respiration, including genera known to contain microbes that methylate Hg. AWD fields were dried-down and re-flooded (one or three times); however oxic periods did not persist long enough in AWD fields to substantially change microbial communities (as observed in Fig. 5).

Although reductions in soil and rice $\mathrm{MeHg}$ concentrations in AWD fields were more modest compared to furrow-irrigated fields, they are worth noting. Beta-diversity patterns for soil microbiotas did not discriminate between flooded and AWD fields (Fig. 5), and the relative abundance of genera known to contain Hg methylators was similar between flooded and AWD fields (Fig. 6, Table 3). However rice farmers prefer AWD over furrow-irrigation because rice yields are not severely compromised (Bouman et al., 2007). For other rice varieties cultivated in the same fields at the same time, grain yield was reduced by $0 \%, 4.6 \%$, and $34 \%$ in the AWD40Flood, AWD60 and furrow-irrigated fields, compared to continuously flooded fields (Table 2). Although soil and rice $\mathrm{MeHg}$ concentrations were lowest in furrow-irrigated fields compared to AWD fields, rice yields in AWD plots were not severely compromised. Rice is a staple food; therefore it is important to consider both nutritional quality and rice yield when implementing water-saving rice cultivation methods.

One limitation of this study concerns the resolution of 16S (v4) rDNA profiling, i.e., genus level. It is important to note that not all members of the same genus perform the same functions, including the ability to methylate $\mathrm{Hg}$ (Gilmour et al., 2011). Therefore, genus-level results likely reflected an overestimate of genera containing Hg methylators. That said, results from the soil microbiome analysis were consistent with profiles of soil and rice MeHg profiles in furrowirrigated fields compared to flooded/AWD fields (Tables 2 and 3), suggesting an association between reduced soil and rice methylmercury concentrations and specific soil microbiomes. Additionally, our study focused on AWD and furrow-irrigation as alternatives to continuous 
flooding, and did not consider other water-saving methods such as the System of Rice Intensification (Bouman et al., 2007). Thus more research is needed to weigh the tradeoffs and benefits of water-saving rice cultivation.

\section{CONCLUSIONS}

Water-saving rice cultivation methods are being implemented globally to address multiple issues, including climate change, water scarcity, groundwater depletion, and arsenic exposure (Bouman and Tuong, 2001; Bouman et al., 2007; California Air Resources Board, 2005; Farooq et al., 2009; Linquist et al., 2015; Massey et al., 2014). Results from this study add to the list of benefits, including reduced rice $\mathrm{MeHg}$ concentrations in AWD fields, with low or minimal changes in rice yields.

\section{ACKNOWLEDGEMENTS}

The authors wish to thank the staff at U.S. Department of Agriculture Dale Bumpers National Rice Research Center in Stuttgart, Arkansas, who contributed their time and resources to this project. The authors also thank three anonymous reviewers for providing constructive comments that greatly improved the manuscript. This research was supported in part by grants to

S. E. Rothenberg from the U.S. Department of Agriculture National Institute of Food and Agriculture Research Initiative (USDA-NIFA) (Award: 2012-69002-19796), the U.S. National Institute Of Environmental Health Sciences of the National Institutes of Health (Award: R15 ES022409), and the U.S. National Institute Loan Replacement Program (Award: L30 ES023165). The content is solely the responsibility of the authors and does not necessarily represent the 
official views of the U.S. National Institutes of Health or the U.S. Department of Agriculture. The authors have no actual or potential conflicts of interest to report. 


\section{REFERENCES}

Alpers, C.N.; Fleck, J.A.; Marvin-DiPasquale, M.; Stricker, C.A.; Stephenson, M.; Taylor, H.E. Mercury cycling in agricultural and managed wetlands, Yolo Bypass, California: spatial and seasonal variations in water quality. Sci. Total Environ. 2014, 484, 276-287.

Bae, H.S., Dierberg, F.E., Ogram, A. Syntrophs dominate sequences associated with the mercury methylation-related gene $h g c A$ in the water conservation areas of the Florida Everglades. Appl. Environ. Microbiol. 2014, 80, 6517-6526.

Bouman, B.A.M.; Tuong, T.P. Field water management to save water and increase its productivity in irrigated rice. Agricult. Water Manag. 2001, 49, 11-30.

Bouman, B.A.M., Lampayan, R.M., Tuong, T.P. Water Management in Irrigated Rice: Coping with Water Scarcity. International Rice Research Institute: Los Banos, Philippines, 2007.

California Air Resources Board. Compliance offset protocol for rice cultivation projects, Adopted June 25, 2015; www.arb.ca.gov/regact/2014/capandtradeprf14/ctriceprotocol.pdf, last accessed 25 June 2016.

Caporaso, J.G.; Lauber, C.L.; Walters, W.A.; Berg-Lyons, D.; Huntley, J.; Fierer, N.; Owens, S.M.; Betley, J.; Fraser, L.; Bauer, M.; Gormley, N.; Gilbert, J.A.; Smith, G.; Knight, R. Ultrahigh-throughput microbial community analysis on the Illumina HiSeq and MiSeq platforms. ISME $J, 2012,6,1621-1624$. 
Chao, A. Nonparametric-estimation of the number of classes in a population. Scand. J. Stat. 1984, $11,265-270$.

Colmer, T. Long-distance transport of gases in plants: a perspective on internal aeration and radial oxygen loss from roots. Plant. Cell Environ. 2003, 26, 17-36.

Edgar, R.C. Search and clustering orders of magnitude faster than BLAST. Bioinformatics 2010, 26, 2460-2461.

Edwards, J.; Johnson, C.; Santos-Medellin, C.; Lurie, E.; Podishetty, N.K.; Bhatnagar, S.; Eisen, J.A.; Sudaresan, V. Structure, variation, and assembly of the root-associated microbiomes of rice. Proc. Natl. Acad. Sci. U.S.A. 2015, 112, E911-E920, doi:10.1073/pnas.1414592112.

Farooq, M.; Kobayashi, N.; Wahid, A.; Ito, O.; Basra, S.M.A. Strategies for producing more rice with less water. Adv. Agron. 2009, 101, 351-388.

Gilmour, C.C.; Elias, D.A.; Kucken, A.M.; Brown, S.D.; Palumbo, A.V.; Schadt, C.W.; Wall, J.D. Sulfate-reducing bacterium Desulfovibrio desulfuricans ND132 as a model for understanding bacterial mercury methylation. Appl. Environ. Microbiol. 2011, 77, 3938-3951. 
Gilmour, C.C.; Podar, M.; Bullock, A.L.; Graham, A.M.; Brown, S.D.; Somenahally, A.C.; Johs, A.; Hurt, R.A., Jr.; Bailey, K.L.; Elias, D.A. Mercury methylation by novel microorganisms from new environments. Environ. Sci. Technol. 2013, 47, 11810-11820.

Hong, C., Yu, X., Liu, J., Cheng, Y., Rothenberg, S.E. Low-level methylmercury exposure through rice ingestion in a cohort of pregnant mothers in rural China. Environ. Res. in press.

Kelly, C.A.; Rudd, J.W.M.; Bodaly, R.A.; Roulet, N.P.; St. Louis, V.L.; Heyes, A.; Moore, T.R.; Schiff, S.; Aravena, R.; Scott, K.J.; Dyck, B.; Harris, R.; Warner, B.; Edwards, G. Increases in fluxes of greenhouse gases and methyl mercury following flooding of an experimental reservoir. Environ. Sci. Technol. 1997, 31, 1334-1344.

Kim, Y.; Liesack, W. Differential assemblage of functional units of paddy soil microbiomes. PloS One 2015 10(4): e0122221. doi:10.1371/journal.pone.0122221.

Liang, L.; Horvat, M.; Cernichiari, E.; Gelcin, B.; Balogh, S. Simple solvent extraction technique for elimination of matrix interferences in the determination of methylmercury in environmental and biological samples by ethylation-gas chromatography-cold vapor atomic fluorescence spectrometry. Talanta 1996, 43, 1883-1888.

Liang, L.; Horvat, M.; Feng, X.; Shang, L.; Li, H.; Pang, P. Re-evaluation of distillation and comparison with $\mathrm{HNO}_{3}$ leaching/solvent extraction for isolation of methylmercury compounds from sediment/soil samples. Appl. Organomet. Chem. 2004, 18, 264-270. 
Linquist, B.A.; Anders, M.M.; Adviento-Borbe, M.A.A.; Chaney, R.L.; Nalley, L.N.; Da Rosa, E.F.F.; Van Kessel, C. Reducing greenhouse gas emissions, water use, and grain arsenic levels in rice systems. Glob. Change Biol. 2015, 21, 407-417.

Liu, Y.R., Yu, R.Q., Zheng, Y.M., He, J.Z. Analysis of the microbial community structure by monitoring an $\mathrm{Hg}$ methylation gene $(h g c A)$ in paddy soils along an $\mathrm{Hg}$ gradient. Appl. Environ. Microbiol. 2014, 80, 2874-2879.

Lozupone, C.; Knight, R. UniFrac: a new phylogenetic method for comparing microbial communities. Appl. Environ. Microbiol. 2005, 71, 8228-8235.

Marvin-DiPasquale, M.; Agee, J.; Jaffe, B. Microbial cycling of mercury in contaminated pelagic and wetlands of San Pablo Bay, California. Environ. Geol. 2003, 43, 260-267.

Marvin-DiPasquale, M.; Windham-Myers, L., Agee, J.L.; Kakouros, E.; Kieu, L.H.; Fleck, J.A.; Alpers, C.N.; Stricker, C. A. Methylmercury production in sediment from agricultural and nonagricultural wetlands in the Yolo Bypass, California, USA. Sci. Total Environ. 2014, 484, 288299.

Massey, J.H.; Walker, T.W.; Anders, M.M.; Smith, M.C.; Avila, L.A. 2014. Farmer adaption of intermittent flooding using multiple-inlet rice irrigation in Mississippi. Agricult. Water Manag. 2014, 146, 297-304. 
Morison, J.I.L.; Baker, N.R.; Mullineaux, P.M.; Davies, W.J. Improving water use in crop production. Phil. Trans. R. Soc. B 2008, 363, 639-658.

Parks, J.M.; Johs, A.; Podar, M.; Bridou, R.; Hurt, R.A.; Smith, S.D.; Tomanicek, S.J.; Qian, Y.; Brown, S.D.; Brandt, C.C.; Palumbo, A.V.; Smith, J.C.; Wall, J.D.; Elias, D.A.; Liang, L.Y. The genetic basis for bacterial mercury methylation. Science 2013, 339, 1332-1335.

Peng, X.; Liu, F.; Wang, W.-X.; Ye, Z.H. Reducing total mercury and methylmercury accumulation in rice grains through water management and deliberate selection of rice cultivars. Environ. Pollut. 2012, 162, 202-208.

Quast, C.; Pruesse, E.; Yilmaz, P.; Gerken, J.; Schweer, T.; Yarza, P.; Peplies, J.; Glöckner, F.O. The SILVA ribosomal RNA gene database project: improved data processing and web-based tools. Nucleic Acids Res. 2013, 41(Database issue), D590-596.

Rothenberg, S.E.; Feng, X., Dong, B., Shang, L., Yin, R., Yuan, X. Characterization of mercury species in brown and white rice (Oryza sativa L.) grown in water-saving paddies. Environ. Pollut. 2011, 159, 1283-1289.

Rothenberg, S. E.; Feng, X.; Zhou, W.; Tu, M.; Jin, B.; You, J. Environment and genotype controls on mercury accumulation in rice (Oryza sativa L.) cultivated along a contamination gradient in Guizhou, China. Sci. Total Environ. 2012, 426, 272-280. 
Rothenberg, S. E.; Feng, X. Mercury cycling in a flooded rice paddy. J. Geophys. Res.: Biogeosci. 2012, 117, G03003, doi:10.1029/2011JG001800.

Rothenberg, S.E.; Windham-Myers, L.; Creswell, J.E. Rice methylmercury exposure and mitigation: a comprehensive review. Environ. Res. 2014, 133, 407-423.

Rothenberg, S.E.; Mgutshini, N.L.; Bizimis, M.; Johnson-Beebout, S.E.; Ramanantsoanirina, A. Retrospective study of methylmercury and other metal(loid)s in Madagascar unpolished rice (Oryza sativa L.). Environ. Pollut. 2015, 196, 125-133.

Sakai, S.; Imachi, H.; Hanada, S.; Ohashi, A.; Harada, H.; Kamagata, Y. Methanocella paludicola gen. nov., sp. nov., a methane-producing archaeon, the first isolate of the lineage 'Rice Cluster I,' and proposal of the new archaeal order Methanocellales ord. nov. Int. J. Syst. Evol. Microbiol. 2008, 58, 929-936.

Sakai, S.; Conrad, R.; Liesack, W.; Imachi, H. Methanocella arvoryzae sp. nov., a hydrogenotrophic methanogen isolated from rice field soil. Int. J. Syst. Evol. Microbiol. 2010, 60, 2918-2923.

Schaefer, J.K., Kronberg, R.M., Morel, F.M.M., Skyllberg, U. Detection of a key Hg methylation gene, hgcA, in wetland soils. Environ. Microbiol. Rep. 2014, 6, 441-447. 
Smith, S.D.; Bridou, R.; Johs, A.; Parks, J.M.; Elias, D.A.; Hurt, Jr. R.A.; Brown, S.D.; Podar, M.; Wall, J.D. Site-directed mutagenesis of $\mathrm{HgcA}$ and $\mathrm{HgcB}$ reveals amino acid residues important for mercury methylation. Appl. Environ. Microbiol. 2015, 81, 3205-3217.

U.S. Environmental Protection Agency (USEPA). Method 1630, Methyl Mercury in Water by Distillation, Aqueous Ethylation, Purge and Trap, and CVAFS, EPA 821-R-01-020: Washington, DC, 2001.

U.S. Environmental Protection Agency (USEPA). Method 7473, Mercury in Solids and Solutions by Thermal Decomposition Amalgamation, and Atomic Absorption Spectrophotometry: Washington, DC, 2007.

Wang, X.; Ye, Z.; Li, B.; Huang, L.; Meng, M.; Shi, J.; Jiang, G. Growing rice aerobically markedly decreases mercury accumulation by reducing both $\mathrm{Hg}$ bioavailability and the production of MeHg. Environ. Sci. Technol. 2014, 48, 1878-1885.

Windham-Myers, L.; Fleck, J.A.; Ackerman J.T.; Marvin-DiPasquale, M.; Stricker, C.A.; Heim, W.A.; Bachand, P.A.M.; Eagles-Smith, C.A.; Gill, G.; Stephenson, M.; Alpers, C.N. Mercury cycling in agricultural and managed wetlands: a synthesis of methylmercury production, hydrologic export, and bioaccumulation from an integrated field study. Sci. Total Environ. 2014a, $484,221-231$. 
Windham-Myers, L.; Marvin-DiPasquale, M.; Stricker, C.A.; Agee, J.J.; Kieu, L.H.; Kakouros, E. Mercury cycling in agricultural and managed wetlands of California, USA: experimental evidence of vegetation-driven changes in sediment biogeochemistry and methylmercury production. Sci.

Total Environ. 2014b, 484, 300-307.

Windham-Myers, L.; Marvin-DiPasquale, M.; Kakouros, E., Agee, J.L.; Kieu, L.H.; Stricker, J.A.; Ackerman, J.T. Mercury cycling in agricultural and managed wetlands on California, USA: seasonal influences of vegetation on mercury methylation, storage, and transport. Sci. Total Environ. 2014c. 484, 308-318.

Xiang, S.R., Doyle, A., Holden, P.A., Schimel, J.P. Drying and rewetting effects on C and N mineralization and microbial activity in surface and subsurface California Grassland soils. Soil Biol. Biochem. 2008, 40, 2281-2289.

Yin, R., Feng, X., Meng, B. Stable mercury isotope variation in rice plants (Oryza sativa) from the Wanshan mercury mining district, SW China. Environ. Sci. Technol. 2013. 47, 2238-2245.

Yoshida, N.; Ye, L.; Baba, D.; Katayama, A. A novel Dehalobacter species is involved in extensive 4,5,6,7-tetrachlorophthalide dechlorination. Appl. Environ. Microbiol. 2009, 75, 24002405. 


\section{TABLES}

Table 1. Quality assurance/quality control for analyses of rice and soil mercury concentrations.

\begin{tabular}{|c|c|c|c|c|c|c|}
\hline & \multicolumn{5}{|c|}{ Standard reference materials } & \\
\hline & $\begin{array}{c}\text { NIST 1515 } \\
\text { \% (n) }\end{array}$ & $\begin{array}{c}\text { Tort-2 } \\
\text { \% (n) }\end{array}$ & $\begin{array}{c}\text { IAEA-086 } \\
\text { \% (n) }\end{array}$ & $\begin{array}{c}\text { BCR 580 } \\
\text { \% (n) }\end{array}$ & $\begin{array}{c}\text { RPD } \\
\text { \% (n) }\end{array}$ & $\begin{array}{c}\text { Matrix spike } \\
\text { \% (n) }\end{array}$ \\
\hline THg & $89(4)$ & $102(2)$ & $87(2)$ & NA & $9.3(29)$ & NA \\
\hline MeHg & NA & $95(2)$ & NA & $69(2)$ & $18(6)$ & $94(3)$ \\
\hline
\end{tabular}

Total mercury $(\mathrm{THg})$, methylmercury $(\mathrm{MeHg})$, percent recovery $(\%)$, number of measurements $(\mathrm{n})$, relative percent difference (RPD) between replicate analyses. 
Table 2. Average $( \pm$ SD) concentrations of mercury in soil and rice, and grain yield ( $n=16$ fields, 4 fields per treatment). The fold-change reflects the ratio between the results in treatments 1-3 and treatment 4.

\begin{tabular}{|l|l|l|l|l|l|c|}
\hline & $\begin{array}{l}\text { Treatment 1 } \\
\text { Flood }\end{array}$ & $\begin{array}{l}\text { Treatment 2 } \\
\text { AWD40- } \\
\text { Flood }\end{array}$ & $\begin{array}{l}\text { Treatment 3 } \\
\text { AWD60 }\end{array}$ & $\begin{array}{l}\text { Treatment 4 } \\
\text { Furrow- } \\
\text { Irrigated }\end{array}$ & $\begin{array}{l}\text { All } \\
\text { treatments }\end{array}$ & $\begin{array}{l}\text { Fold- } \\
\text { change }\end{array}$ \\
\hline $\begin{array}{l}\text { Soil THg } \\
\text { (ng/g) }\end{array}$ & $22 \pm 2.3$ & $20 \pm 0.66$ & $22 \pm 2.4$ & $22 \pm 5.8$ & $21 \pm 3.2$ & 0.95 \\
\hline $\begin{array}{l}\text { Soil MeHg } \\
\text { (ng/g) }\end{array}$ & $0.29 \pm 0.27$ & $0.20 \pm 0.16$ & $0.078 \pm 0.046$ & $0.013 \pm$ \\
0.0035 & $0.15 \pm 0.18$ & 15 \\
\hline $\begin{array}{l}\text { Rice THg } \\
\text { (ng/g) }\end{array}$ & $13 \pm 11$ & $6.4 \pm 5.6$ & $9.3 \pm 4.8$ & $0.68 \pm 0.039$ & $7.4 \pm 7.6$ & 14 \\
\hline $\begin{array}{l}\text { Rice MeHg } \\
\text { (ng/g) }\end{array}$ & $11 \pm 10$ & $5.9 \pm 5.6$ & $8.0 \pm 4.6$ & $0.17 \pm 0.086$ & $6.3 \pm 7.0$ & 50 \\
\hline $\begin{array}{l}\text { BAF THg } \\
\text { (unitless) }\end{array}$ & $0.60 \pm 0.50$ & $0.32 \pm 0.29$ & $0.44 \pm 0.23$ & $0.032 \pm$ & $0.35 \pm 0.35$ & 14 \\
\hline $\begin{array}{l}\text { BAF MeHg } \\
\text { (unitless) }\end{array}$ & $180 \pm 300$ & $94 \pm 150$ & $120 \pm 39$ & $13 \pm 7.2$ & $100 \pm 170$ & 9.7 \\
\hline $\begin{array}{l}\text { BAF MeHg/THg } \\
\text { (unitless) }\end{array}$ & $260 \pm 370$ & $180 \pm 180$ & $420 \pm 450$ & $430 \pm 240$ & $320 \pm 310$ & 0.67 \\
\hline $\begin{array}{l}\text { Grain yield } \\
\text { (Mg ha }{ }^{\text {a }} \text { ) }\end{array}$ & 11.22 & 11.53 & 10.70 & 7.38 & 10.21 & 1.5 \\
\hline
\end{tabular}

AWD (alternating wetting and drying), BAF (Bioaccumulation factor), $\mathrm{MeHg}$ (methylmercury ), THg (total mercury) ${ }^{\mathrm{a}} \mathrm{SD}$ not available 
1 Table 3. Average ( $\pm \mathrm{SD})$ percent relative abundance of microorganisms belonging to genera known to contain mercury methylators;

2 genera are listed from most abundant to least abundant for all treatments ( $\mathrm{n}=16$ fields, 4 fields per treatment). The fold-change reflects

3 the ratio between the average percent relative abundance of genera present in treatments 1-3 and treatment 4.

\begin{tabular}{|c|c|c|c|c|c|c|c|c|c|c|}
\hline Phylum & Class & Order & Family & Genus & $\begin{array}{l}\text { Treatment } 1 \\
\text { Flood }\end{array}$ & $\begin{array}{c}\text { Treatment } 2 \\
\text { AWD40-Flood }\end{array}$ & $\begin{array}{l}\text { Treatment } 3 \\
\text { AWD60 }\end{array}$ & $\begin{array}{c}\text { Treatment } 4 \\
\text { Furrow- } \\
\text { irrigated }\end{array}$ & $\begin{array}{c}\text { All } \\
\text { treatments }\end{array}$ & $\begin{array}{l}\text { Fold- } \\
\text { change }\end{array}$ \\
\hline $\begin{array}{l}\text { Proteo- } \\
\text { bacteria }\end{array}$ & $\begin{array}{l}\text { Deltaproteo- } \\
\text { bacteria }\end{array}$ & Desulfuromonadales & Geobacteraceae & Geobacter & $\begin{array}{c}0.029 \\
(0.030)\end{array}$ & $\begin{array}{c}0.014 \\
(0.0074)\end{array}$ & $\begin{array}{c}0.029 \\
(0.010)\end{array}$ & $\begin{array}{c}0.011 \\
(0.011)\end{array}$ & $\begin{array}{c}0.021 \\
(0.097)\end{array}$ & 2.2 \\
\hline Chlorflexi & Anaerolinea & Anaerolineales & Anaerolineaceae & Anaerolinea & $\begin{array}{c}0.0062 \\
(0.0036)\end{array}$ & $\begin{array}{c}0.0046 \\
(0.0029)\end{array}$ & $\begin{array}{c}0.0068 \\
(0.0041)\end{array}$ & $\begin{array}{c}0.00060 \\
(0.00018)\end{array}$ & $\begin{array}{c}0.0045 \\
(0.0028)\end{array}$ & 9.8 \\
\hline $\begin{array}{l}\text { Proteo- } \\
\text { bacteria }\end{array}$ & $\begin{array}{l}\text { Deltaproteo- } \\
\text { bacteria }\end{array}$ & Desulfovibrionales & $\begin{array}{l}\text { Desulfo- } \\
\text { vibrionaceae }\end{array}$ & Desulfovibrio & $\begin{array}{c}0.0016 \\
(0.0012) \\
\end{array}$ & $\begin{array}{c}0.00073 \\
(0.00025) \\
\end{array}$ & $\begin{array}{c}0.0019 \\
(0.0012) \\
\end{array}$ & $\begin{array}{l}0.000083 \\
(0.00017) \\
\end{array}$ & $\begin{array}{c}0.0011 \\
(0.00084) \\
\end{array}$ & 17 \\
\hline $\begin{array}{l}\text { Proteo- } \\
\text { bacteria }\end{array}$ & $\begin{array}{l}\text { Deltaproteo- } \\
\text { bacteria }\end{array}$ & Syntrophobacterales & Syntrophaceae & Syntrophus & $\begin{array}{c}0.00071 \\
(0.00047)\end{array}$ & $\begin{array}{c}0.00088 \\
(0.00015)\end{array}$ & $\begin{array}{c}0.00048 \\
(0.00029)\end{array}$ & 0 & $\begin{array}{c}0.00052 \\
(0.00038)\end{array}$ & NA \\
\hline Spirochaetea & Spirochaetia & Spirochaetales & Spirochaetaceae & Spirochaeta & $\begin{array}{c}0.00033 \\
(0.00031)\end{array}$ & $\begin{array}{l}0.00066 \\
(0.0010)\end{array}$ & $\begin{array}{l}0.00071 \\
(0.0010)\end{array}$ & $\begin{array}{c}0.00028 \\
(0.00052)\end{array}$ & $\begin{array}{c}0.00050 \\
(0.00022)\end{array}$ & 2.0 \\
\hline $\begin{array}{l}\text { Proteo- } \\
\text { bacteria }\end{array}$ & $\begin{array}{l}\text { Deltaproteo- } \\
\text { bacteria }\end{array}$ & Syntrophobacterales & $\begin{array}{l}\text { Syntro- } \\
\text { phorhabdaceae }\end{array}$ & $\begin{array}{l}\text { Syntro- } \\
\text { phorhabdus }\end{array}$ & $\begin{array}{c}0.00046 \\
(0.00033)\end{array}$ & $\begin{array}{c}0.00045 \\
(0.00029)\end{array}$ & $\begin{array}{c}0.00042 \\
(0.00047)\end{array}$ & 0 & $\begin{array}{c}0.00033 \\
(0.00022)\end{array}$ & NA \\
\hline $\begin{array}{l}\text { Eury- } \\
\text { archaeota }\end{array}$ & $\begin{array}{l}\text { Methano- } \\
\text { microbia }\end{array}$ & Methanomicrobiales & $\begin{array}{l}\text { Methano- } \\
\text { regulaceae }\end{array}$ & Methanoregula & $\begin{array}{c}0.00056 \\
(0.00065) \\
\end{array}$ & $\begin{array}{c}0.00053 \\
(0.00052) \\
\end{array}$ & $\begin{array}{c}0.00020 \\
(0.00036) \\
\end{array}$ & 0 & $\begin{array}{c}0.00032 \\
(0.00027) \\
\end{array}$ & NA \\
\hline $\begin{array}{l}\text { Eury- } \\
\text { archaeota }\end{array}$ & $\begin{array}{l}\text { Methano- } \\
\text { microbia }\end{array}$ & Methanocellales & $\begin{array}{l}\text { Methano- } \\
\text { cellaceae }\end{array}$ & Methanocella & $\begin{array}{c}0.00054 \\
(0.00060) \\
\end{array}$ & $\begin{array}{l}0.000037 \\
(0.00049) \\
\end{array}$ & $\begin{array}{c}0.00037 \\
(0.00043) \\
\end{array}$ & $\begin{array}{l}0.0000083 \\
(0.000012) \\
\end{array}$ & $\begin{array}{c}0.00032 \\
(0.00022) \\
\end{array}$ & 51 \\
\hline Chlorflexi & $\begin{array}{l}\text { Dehalo- } \\
\text { coccoidetes }\end{array}$ & Dehalococcoidales & $\begin{array}{l}\text { Dehalo- } \\
\text { coccoidaceae }\end{array}$ & $\begin{array}{l}\text { Dehalo- } \\
\text { coccoides }\end{array}$ & $\begin{array}{c}0.00038 \\
(0.00040)\end{array}$ & $\begin{array}{c}0.00058 \\
(0.00041)\end{array}$ & $\begin{array}{c}0.00018 \\
(0.00021)\end{array}$ & 0 & $\begin{array}{c}0.00029 \\
(0.00025)\end{array}$ & NA \\
\hline $\begin{array}{l}\text { Proteo- } \\
\text { bacteria }\end{array}$ & $\begin{array}{l}\text { Deltaproteo- } \\
\text { bacteria }\end{array}$ & Syntrophobacterales & Syntrophaceae & Smithella & $\begin{array}{c}0.000033 \\
(0.000066)\end{array}$ & $\begin{array}{c}0.00017 \\
(0.00033)\end{array}$ & $\begin{array}{c}0.00055 \\
(0.00079)\end{array}$ & 0 & $\begin{array}{c}0.00019 \\
(0.00025)\end{array}$ & NA \\
\hline $\begin{array}{l}\text { Proteo- } \\
\text { bacteria }\end{array}$ & $\begin{array}{l}\text { Deltaproteo- } \\
\text { bacteria }\end{array}$ & Desulfarculales & $\begin{array}{l}\text { Desul- } \\
\text { farculaceae }\end{array}$ & Desulfarculus & 0 & 0 & $\begin{array}{c}0.00030 \\
(0.00060) \\
\end{array}$ & 0 & $\begin{array}{l}0.000075 \\
(0.00015) \\
\end{array}$ & NA \\
\hline $\begin{array}{l}\text { Proteo- } \\
\text { bacteria }\end{array}$ & $\begin{array}{l}\text { Deltaproteo- } \\
\text { bacteria }\end{array}$ & Desulfobacterales & $\begin{array}{l}\text { Dessulfo- } \\
\text { bulbaceae }\end{array}$ & Desulfobulbus & $\begin{array}{c}0.00010 \\
(0.00020) \\
\end{array}$ & $\begin{array}{c}0.00012 \\
(0.00011) \\
\end{array}$ & $\begin{array}{l}0.000083 \\
(0.00010) \\
\end{array}$ & 0 & $\begin{array}{c}0.000075 \\
(0.000052)\end{array}$ & NA \\
\hline Firmicutes & Clostridia & Clostridiales & Peptococcaceae & $\begin{array}{l}\text { Desulfo- } \\
\text { sporosinus }\end{array}$ & $\begin{array}{c}0.000050 \\
(0.000064)\end{array}$ & $\begin{array}{c}0.00010 \\
(0.00020) \\
\end{array}$ & $\begin{array}{c}0.00012 \\
(0.00011) \\
\end{array}$ & $\begin{array}{c}0.000017 \\
(0.000033)\end{array}$ & $\begin{array}{c}0.000071 \\
(0.000046)\end{array}$ & 5.3 \\
\hline Bacteroidetes & Bacteroidia & Bacteroidales & Bacteroidaceae & Bacteroides & $\begin{array}{c}0.00010 \\
(0.00012) \\
\end{array}$ & $\begin{array}{c}0.000083 \\
(0.000084) \\
\end{array}$ & $\begin{array}{c}0.000050 \\
(0.000033)\end{array}$ & $\begin{array}{c}0.000033 \\
(0.000038) \\
\end{array}$ & $\begin{array}{c}0.000066 \\
(0.000030)\end{array}$ & 2.3 \\
\hline $\begin{array}{l}\text { Proteo- } \\
\text { bacteria }\end{array}$ & $\begin{array}{l}\text { Deltaproteo- } \\
\text { bacteria }\end{array}$ & Syntrophobacterales & Syntrophaceae & Desulfomonile & $\begin{array}{c}0.000033 \\
(0.000066)\end{array}$ & $\begin{array}{c}0.000050 \\
(0.000064)\end{array}$ & $\begin{array}{c}0.000066 \\
(0.000054)\end{array}$ & 0 & $\begin{array}{c}0.000037 \\
(0.000028)\end{array}$ & NA \\
\hline \multirow[t]{2}{*}{$\begin{array}{l}\text { Eury- } \\
\text { archaeota }\end{array}$} & $\begin{array}{l}\text { Methano- } \\
\text { microbia }\end{array}$ & Methanomicrobiales & $\begin{array}{l}\begin{array}{l}\text { Methano- } \\
\text { spirillaceae }\end{array} \\
\end{array}$ & $\begin{array}{l}\text { Methano- } \\
\text { spirillum }\end{array}$ & $\begin{array}{c}0.000033 \\
(0.000038) \\
\end{array}$ & $\begin{array}{c}0.000017 \\
(0.000033) \\
\end{array}$ & 0 & 0 & $\begin{array}{c}0.000012 \\
(0.000016) \\
\end{array}$ & NA \\
\hline & & & & $\begin{array}{l}\text { All } \\
\text { genera }\end{array}$ & $\begin{array}{c}0.040 \\
(0.025) \\
\end{array}$ & $\begin{array}{c}0.023 \\
(0.006) \\
\end{array}$ & $\begin{array}{c}0.041 \\
(0.010) \\
\end{array}$ & $\begin{array}{c}0.012 \\
(0.011) \\
\end{array}$ & $\begin{array}{c}0.029 \\
(0.018) \\
\end{array}$ & 2.9 \\
\hline
\end{tabular}




\section{The effects of water-saving rice cultivation on the diversity of genera, which are known to include microbes that methylate mercury}
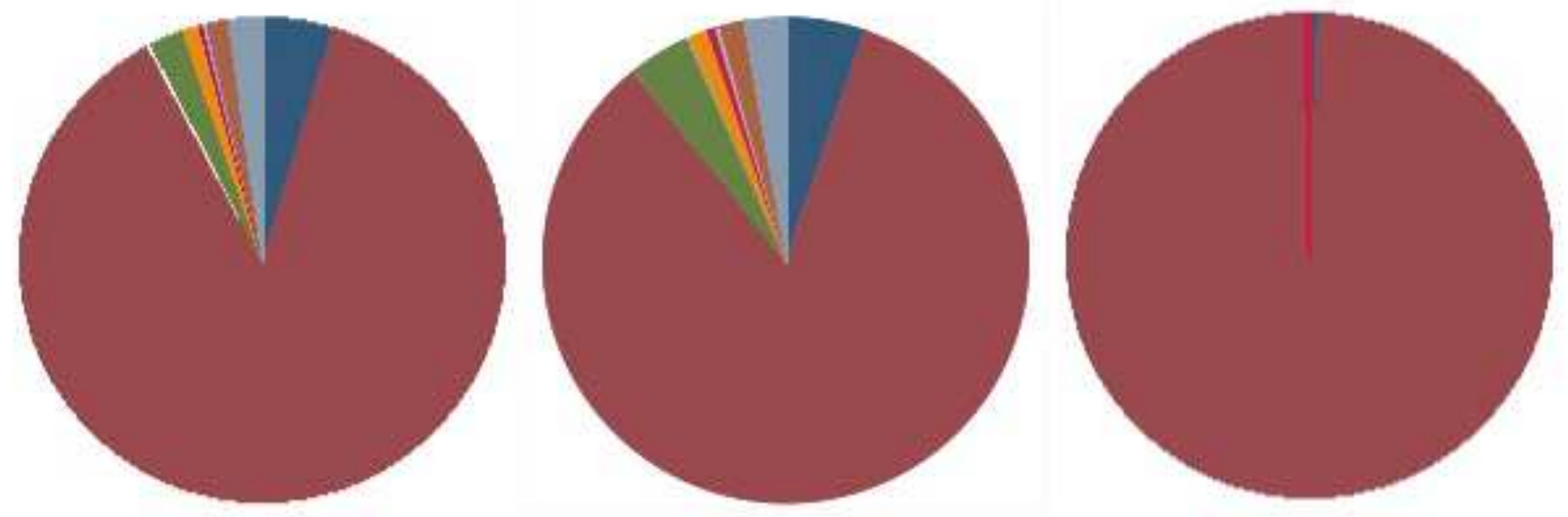

Flooded

Alternating wetting and drying Furrow-irrigated (0 dry-downs)

(1 or 3 dry-downs)

(9 dry-downs) 